ARTIKKELI

\title{
HUUMORI JA MEÄNKIELISTEN TILALLINEN IDENTITEETTI
}

\author{
Juha Ridanpää
}

Tässä artikkelissa tarkastellaan, miten Ruotsissa asuvat ja meänkieltä puhuvat ihmiset ja yhteisöt käyttävät huumoria sekä jaettujen että ristiriitaisten identiteettien ylläpitämisen ja vahvistamisen narratiivisena keinona. Kuten nauru esikognitiivisena affektina, on huumori kommunikatiivisena ja kielellisenä prosessina aina ollut olennainen osa sitä, miten inmiset muodostavat maailmankuvansa, käsityksensä tilasta, alueista, paikoista, kulttuurista ja yhteiskunnasta, jokainen omalla luovalla tavallaan. Samoin huumorilla on keskeinen rooli siinä, miten ihmisryhmiin kohdistuviin valtasuhteisiin ja yhteiskunnalliseen epäoikeudenmukaisuuteen liittyvien kysymysten kanssa voidaan elää. Itse asiassa on esitetty, että sosiaalisen elämän ylläpysyminen ja yhteenkuuluvuuden tunne ovat suorassa yhteydessä huumorin, naurun ja ivailun pitkään traditioon (Billig 2005; Davies 1990; Palmer 1993).

Kriittisissä tulkinnoissa esitetään usein, että asioiden näkeminen koomisina pohjautuu stereotypioiden varaan rakentuvaan maailmankuvaan, jossa yksilön tai ryhmän identiteetti muotoutuu "meidän" ja "heidän" jyrkän erottelun kautta (vrt. Ridanpää 2014a). Merkittävä osa huumorin yhteiskunnallisuuteen keskittyneestä tutkimuksesta onkin kohdistunut siihen, kuinka etniset ja kielelliset vähemmistöt ovat joutuneet naurun ja pilkan kohteiksi ja kuinka huumori, sosiaaliskulttuurisena ilmiönä, edustaa eri medioiden kautta samoin kuin arjen tasolla tapahtuvaa alistavaa toimintaa. Huumori ymmärretään esimerkiksi toiseuteen, seksismiin tai rasismiin liittyvänä kielellisenä käytäntönä, "aseena", jonka avulla inmisryhmien eriarvoisuus pysyy yllä (Hutcheon 1994).

Toisaalta on erittäin tärkeä huomioida se, että etnisten vähemmistöjen identiteettiä, samoin kuin ryhmään kuulumisen tunnetta, voidaan myös vahvistaa huumorin avulla, jolloin huumori tulee kiinteäksi osaksi kansanperinnettä. Esimerkiksi Seppo Knuuttilan (1992) tutkimuksessa on erinomaisesti havainnollistettu, kuinka kansanomainen maailmankuva ja huumori yhtenä kerronnan muotona ovat kiinteästi sidoksissa toisiinsa. Siinä missä Knuuttila näkee kaskut ja folkloren laajemminkin vaihtoehtoisten maailmankuvien ilmaisijana, ymmärretään huumori tässä artikkelissa identiteetin ja yhteiskunnallisuuden välisen yhteen kietoutumisen muotona. Huumori on osa pieniä kertomuksia, joissa suuret kertomukset haastetaan. Tähän liittyen, folkloren ei tule nähdä muotoutuvan kulttuurin yliyhteisöllisyyden, vaan paremminkin inhimillisen toiminnan, vuorovaikutuksen ja aktiivisen merkityksenannon kautta (Pöysä 2012, 28-29). 
Tässä artikkelissa tarkastelen Ruotsin puoleisessa Tornionlaaksossa asuvan meänkieltä puhuvan vähemmistön tilallista, kielellistä ja kulttuurista identiteettiä sekä sitä, miten identiteettiä voidaan vahvistaa ja pitää yllä huumorin avulla. Meänkielisiin vähemmistöihin liittyvissä tutkimuksissa on ollut usein lähtökohtana se, kuinka ryhmän identiteetti rakentuu marginaalisuuden kautta osana ruotsalaista yhteiskuntaa (Heith 2012; Magnfrídur Júlíusdóttir \& Yvonne Gunnarsdotter 2007). Tietoisuus oman kielen ja identiteetin marginaalisuudesta nousi alueella esiin vasta 1980-luvulla, jolloin oman identiteetin, kulttuurin ja kielen, "meidän kielen", eli "meänkielen" säilyttämisen itseisarvo ymmärrettiin ja työ kielen ja kulttuurin revitalisaation puolesta käynnistettiin.

Viimeisten vuosikymmenten aikana huumorilla on ollut keskeinen rooli meänkielen ja tornionlaaksolaisen identiteetin ylläpitämisessä. Tämä on ollut havaittavissa useiden populaarikulttuurin piirissä itsensä läpilyöneiden tornionlaaksolaisten taitelijoiden, kuten kirjailija Mikael Niemen ja Raj-Raj Bandin, saavuttamassa suosiossa. Erityisesti Niemen huumorilla on ollut merkittävä rooli Ruotsin puoleisen Tornionlaakson tunnettavuuden, imagon ja alueen identiteetin muotoutumisessa (ks. Ridanpää 2014a). Huumorin avulla alueesta tuotetaan ulkopuolisille mielikuvia, mutta tärkeää on korostaa myös sitä, kuinka huumori on väline, joka toimii arjen tasolla, sekä yksilön että jaettujen identiteettien tuottajana ja välittäjänä.

Tässä artikkelissa ymmärrän huumorin paitsi kielellisenä välineenä, myös laajempana näkökulmana, jonka kautta maailmaa jäsennetään. Tarkastelen, kuinka Ruotsin puoleisessa Tornionlaaksossa asuvat meänkieliset käyttävät huumoria ryhmäidentiteettiä ylläpitävänä narratiivisena välineenä. Käsittelen myös sitä, miten Tornionlaakson alueellinen historia, valtasuhteet ja kielellisenä vähemmistönä elämisen arki tulevat esiin paikallisessa huumorissa. Tutkimus perustuu kahdeksaan eri kulttuuritoimijoiden kanssa käytyyn ryhmäkeskusteluun, joissa huumoria lähestyttiin samanaikaisesti sekä keskustelun temaattisena aiheena että kerronnan muotona. Tein haastattelut syyskuun 2015 ja helmikuun 2016 välisenä aikana. Tutkimuksen teoreettisena näkökulmana käytän narratiivisen identiteetin käsitettä, sen tilallisia merkityksiä sekä suhdetta huumorin eri muotoihin.

\section{Tila, IDENTIteetti JA haUsKat KeRtomukset}

Kulttuurimaantieteellisessä tutkimuksessa on tarkasteltu ihmisen, ympäristön ja yhteiskunnan välistä vuorovaikutusta useista teoreettis-filosofisista näkökulmista. Kun 1950-luvulta alkaen ihmisen toimintaa tilassa pyrittiin selittämään lähinnä matemaattisen mallintamisen avulla, kääntyi 1970-luvun humanistisessa maantieteessä huomio siihen, kuinka ihmisen subjektiviteetti ja identiteetti ovat keskeisesti tilaan ja paikkaan sidoksissa olevia ilmiöitä. Tätä pyrittiin havainnollistamaan uusien käsitteiden, kuten topofilia (Tuan 1974) ja paikan tuntu (Relph 1976), avulla. Viimeisen kahden vuosikymmenen aikana on yhä enemmän korostettu sitä, kuinka epästabiilista ilmiöstä identiteetissä on kyse (ks. Brubaker \& Cooper 2000). Maantieteellisessä tutkimuksessa on painotettu erityisesti sitä, miten identiteetti, eli ihmisen ja ihmisryhmien käsitys "itsestä", rakentuu pitkälti arjen käytännöissä ja kokemuksissa, aina suhteessa "toiseen" (Massey 2005, 192). 
Kielen yksi keskeisimmistä tehtävistä on ryhmäidentiteetin luominen ja ylläpitäminen (Edwards 2010). Margaret Somers $(1994,606)$ on korostanut, että sosiaaliset identiteetit muotoutuvat kertomuksissa, tai päinvastoin, ilman kertomuksia sosiaalisen identiteetin muotoutuminen olisi mahdotonta. Kysymys "kuka minä olen?" saa vastauksensa kertomuksena siitä, missä ja milloin olen syntynyt, käynyt kouluni, mennyt naimisiin, jne. Tarinoiden avulla ihmiset tuottavat käsitystä itsestään, keitä he ovat, keitä he eivät ole, ja kuinka tämä yhteenkuuluminen on sidoksissa tilallisiin ja alueellisiin luokitteluihin (Prokkola \& Ridanpää 2011), eli siihen, kuinka inmisten tilallinen identiteetti muotoutuu. Tässä yhteydessä voidaan käyttää myös termiä narratiivinen identiteetti, jolla viitataan laajemmin siihen, kuinka yksilöt muodostavat henkilökohtaiset tarinansa suhteessa laajempiin yhteiskunnallisiin ja kulttuurisiin kysymyksiin sekä siihen, kuinka yhteisöt muodostavat tilallisen identieettinsä suhteessa (jaettuihin) kertomuksiin (Hearn 2007). Kertomusten myötä muotoutuu käsitys "meidän" ja "heidän" välillä olevasta kategorisesta erosta, ja samalla ryhmän identiteetti saa merkityksensä (vrt. Massay 2005).

Kuten Seppo Knuuttila $(2015,7)$ toteaa vuoden 2015 Kalevalaseuran vuosikirjan Huumorin skaalat avauslauseessa, "(h)uumorin ja koomisen artikulaatiomahdollisuudet ovat rajattomat, aivan niin kuin esityksen ja tekstin, puhunnan ja kielen tai merkityksen ja tarkoituksen keskinäiset kytkennät". Huumori on kiinteä osa arjen kommunikaatiota, mikä näkyy myös siinä, että huumoriin yhdistyvät merkitykset otetaan usein itsestäänselvyyksinä. Useissa tutkimuksissa on painotettu sitä, miten ryhmäidentiteetti on kiinteässä yhteydessä kertomuksiin sisältyvään huumoriin (esim. Rothwell ym. 2011; Weckström 2011). Tästä yksinkertaisimpana esimerkkinä voidaan käyttää niin sanottua etnistä huumoria. Tutkimuksissa on esimerkiksi tarkasteltu, miten maahanmuuttajille nauru on toiminut keskeisenä ryhmää yhdistävänä kommunikatiivisena työkaluna, samalla auttaen sopeutumaan uuteen kulttuuriseen ympäristöön (Salamon 2011; Shiftman \& Katz 2005).

Etninen ja erityisesti rasistinen huumori on klassinen esimerkki stereotypioiden varaan rakentuvasta diskurssista (blason populaire), jonka yleisesti (ja osin virheellisesti) ajatellaan olevan kohdettaan alistavaa puhetta (Cundall 2012). Etnisiin ryhmiin kohdistetulle huumorille, erityisesti vitseille, on ominaista, etteivät niiden sisällään pitämät viestit pysy yhteiskunnallisen kehityksen kyydissä (Kuipers \& van der Ent 2016). Etnisyyden ja huumorin välisestä suhteesta puhuttaessa palaudutaan usein kysymykseen siitä, kuinka huumori ei ole koskaan viatonta, vaan aina jollakin tapaa poliittisesti latautunutta ja "vakavaa" (Ridanpää 2014b). Tätä kysymystä voidaan lähestyä kahdesta eri näkökulmasta: ensinnäkin, etniset vähemmistöt ovat, voisi sanoa jo perinteisesti, olleet pilkan kohteita - pilkan, jossa ivaava huumori on ollut keskeisessä roolissa. Suomessa kysymys etnisen huumorin epäkorrektiudesta nousi pinnalle 1980-luvun puolivälissä Pirkka-Pekka Peteliuksen ja Aake Kallialan esittämien nunnuka-lai-laa-saamelaisten aiheuttaman kohun myötä. Saamelaiset näkivät etnisen identiteettinsä esittämisen stereotypioihin tukeutuvien vitsien kautta loukkaavana ja samalla aiheesta nousi Suomessa käytännössä ensimmäinen julkinen keskustelu, jossa huumorin viattomuus kyseenalaistettiin. Huumorintutkimuksessa onkin painotettu, että kaikki etnisyyteen kohdistuva huumori pohjautuu stereotypioiden varaan rakentuvaan valta-asetelmaan, toisin 
sanoen, etninen huumori on jo lähtökohtaisesti loukkaavaa (Hughes 2003; Perks 2010; Weaver 2011).

Sen sijaan toisessa näkökulmassa huumorin suhde etnisyyteen nähdään tietyllä tapaa emansipatorisena. Tämän näkökulman mukaan huumori toimii työkaluna, jonka avulla etnisyyteen kohdistuvia hegemonisia kertomuksia voidaan haastaa tai jopa kääntää päälaelleen (Mascha 2008; Ridanpää 2007; 2010). Kansallisten vähemmistöjen tapauksessa onkin puhuttu siitä, kuinka itseironian avulla vähemmistöryhmät voivat peilata omaa identiteettiään (ks. Davies 1998; 2002). Samoin huumori toimii hyvänä työkaluna yhteenkuuluvuudentunteen ylläpitämisessä (Terrion \& Ashforth 2002). Onkin esitetty, että ryhmäidentiteetin ja -koheesion säilyttäminen on huumoriin sisäänkirjoitettu päämäärä (Davies 1990; Palmer 1993), erityisesti osana inmisten arkista kanssakäymistä (Lynch 2010).

\section{MeÄNKIELI JA TORNIONLAAKSON ALUEELLINEN IDENTITEETTI}

Meänkielen, "meidän kielen", kehittymisen eri vaiheet ovat kiinteässä yhteydessä alueen identiteetin muotoutumiseen. Meänkielen kehittymisen taustalla on Venäjän keisarikunnan ja Ruotsin välillä 1808-1809 käyty niin sanottu Suomen sota. Sodan päätyttyä Ruotsiin tuolloin kuulunut Suomen alue liitettiin autonomiseksi osaksi Venäjän keisarikuntaa ja länsirajaksi vedettiin edelleenkin Suomen länsirajana oleva Tornionjoki. Samalla kulttuurisesti enemmän tai vähemmän koherentti Tornionlaakson alue jaettiin kahden valtion kesken. Hiljalleen Ruotsin puolelle jäänyt, suomea puhuva väestö joutui voimakkaan ruotsalaistamispaineen kohteeksi. Esimerkiksi suomen puhuminen kouluissa kiellettiin 1900-luvun alussa, ruotsalaiset antropologit pyrkivät todistamaan suomalaisen rodun alempiarvoisuuden, ja samalla suomalaisuudesta tuli häpeänaihe (Heith 2012; Magnfríður Júlíusdóttir \& Yvonne Gunnarsdotter 2007). Tästä huolimatta esimerkiksi poikkinainnin traditio, eli pitkään alueella elänyt käytäntö, missä useimmiten ruotsalainen mies löytää vaimonsa Tornionjoen eli Väylän toiselta puolelta Suomesta, on pitänyt suomalaisuuden traditiota yllä. Suomalaisuuden perintöön on kuitenkin alusta asti liitetty stereotypiat ylikonservatiivisuudesta (Pajalassa syntynyt lestadiolaisuus), patriarkalismista, arvoissa korostuvassa maskuliinisuudesta, perheväkivallan tavanomaisuudesta ja alkoholismista (Cullblom 1997).

Niin sanotun globaalin etnisten renessanssin myötä alkoi myös 1980-luvun Tornionlaaksossa hiljalleen syntyä ajatus siitä, ettei kielellisessä ja kulttuurisessa marginaalisuudessa ollut mitään hävettävää (ks. Lindgren 2000; Winsa 2007). Alueella puhuttu suomen kieli erotti asukkaat muusta ruotsalaisesta yhteiskunnasta, mutta toisaalta se myös yhdisti alueen asukkaita, toimi yhteenkuuluvuuden tunteen, me-hengen, kulmakivenä. Kielitieteellisestä näkökulmasta katsottuna meänkieli on osa suomen kielen peräpohjalaisia murteita, mutta jos kieli ymmärretään poliittisena kysymyksenä, voidaan meänkielen nähdä Ruotsin puoleisen Tornionlaakson alueellisen/tilallisen identiteetin ylläpitämiseen kytköksissä olevana omana itsenäisenä kielenä (Mantila 2000). Kyse oli omasta kielestä, jonka puolesta puhuminen tuli nähdä itsetarkoituksena ja jonka säilymisen edestä tuli tehdä työtä. Kuten paikallisten kanssa käydyissä ryhmäkeskusteluissa tuotiin usein esiin, meänkieli ikään kuin "keksittiin" alueelliseksi, vähemmistöpoliittiseksi työkaluksi. Vuonna 
2000 meänkieli saavutti kulttuurityön myötä itsenäisen vähemmistökielen aseman viidessä eri Ruotsin kunnassa: Gällivaarassa, Kiirunassa, Haaparannalla, Pajalassa ja Övertorneålla.

Meänkielelle tyypillistä on h-kirjaimen voimakas käyttö, ruotsinkielisten lainasanojen hyödyntäminen sekä tietynlainen "pysähtyneisyys" suhteessa siihen, kuinka suomen kieli on Suomen puolella viimeisen kahden vuosisadan aikana kehittynyt (Vaattovaara 2009). Vaikka Bengt Pohjanen on rakentanut meänkielelle oman kielioppinsa, kyse on ensisijaisesti arjen puhekielestä, jota käytetään jatkuvasti rinnakkain ruotsin kielen kanssa, riippuen keskustelun asiayhteydestä sekä puhujan omasta kielitaidosta. Vaikka kielitieteellisessä mielessä ruotsi on läsnä meänkielessä ainoastaan lainasanoissa, käytännön tasolla monikielisyys on meänkielen käyttämiseen liittyvä keskeinen ominaispiirre. On kuitenkin tärkeä korostaa sitä, kuinka meänkieleen keskeisesti kuuluva monikielisyys on koettu enemmänkin "puolikielisyytenä" (Ahola 2006, 28). Tämä on yksi esimerkki kielen käyttämiseen liittyvästä ja ihmisten sisäistämästä alisteisuuden perinteestä, mikä on johtanut häpeään ja toiminut esteenä positiiviselle identifioitumiselle omaan kieleen.

Tällä hetkellä Ruotsin puoleisessa Tornionlaaksossa asuu noin 50000 asukasta, joista Ethnologue: Languages of the World -sivuston mukaan arviolta 30000 on meänkielen puhujia. Meänkielen puhujien määrää on kuitenkin erittäin vaikea arvioida, sillä useat kieltä käyttävät eivät itse ole varmoja omasta kielitaidostaan tai siitä, onko heidän puhumansa kieli suomea vai meänkieltä. Meänkieleen on pitkään liittynyt keskustelu siitä, onko meänkielen tapauksessa varsinaisesti kyse omasta itsenäisestä kielestä vai suomen murteesta. Kuten myös tämän tutkimuksen ryhmäkeskusteluissa nousi esiin, vallitseva näkemys on, että Suomen puolella kyse on suomen murteesta ja vastaavasti Tornionjoen toisella puolella Ruotsissa meänkieli on oma itsenäinen kielensä, jolla on valtion tunnustama legitiimi asema.

Kielen ja kulttuurin suojelemisen puolesta toimiva järjestö Tornionlaaksolaiset (Svenska Tornedalingars Riksförbund STR-T) perustettiin vuonna 1981. Kyseisen järjestön lisäksi useat yksittäiset henkilöt ovat olleet merkittävässä roolissa meänkielen ja alueen kulttuuriperinteen säilyttämisen puolesta tehtävässä työssä. Poliitikko Ragnar Lassinantti (1915-1985) teki laajamittaista työtä Ruotsissa asuvien suomenkielisten aseman puolesta. Vastaavasti meänkielen itsenäisen aseman puolesta käydyssä taistelussa Bengt Pohjasen kulttuurityö on ollut merkittävää. Pohjanen kirjoitti ensimmäisen meänkieltä sisältävän kaunokirjallisen teoksen Kasaland vuonna 1984 ja meänkielen kielioppikirja, Meänkielen kramatiikki, ilmestyi vuonna 1996. Yhtenä Pohjasen kulttuuriprojektina meänkieliset saivat myös niin sanotun "territoriaalisen muotonsa", eli syntyi ajatus valtiorajojen ylitse kulkevasta Meänmaasta, jolle tehtiin oma lippunsa (meänflagu), ja jonka asukkaat voivat hakea itselleen symbolisen Meänmaan kansalaisuuden todistavan passin, jolla paikallisista kaupoista voi saada alennusta (ks. Prokkola \& Ridanpää 2011).

Viime vuosien aikana huumorin merkitys osana tornionlaaksolaisen identiteetin ylläpysymistä on noussut keskeiseen rooliin. Ensisysäyksenä huumorin suosiolle toimi vuonna 2000 julkaistu Mikael Niemen jättimenestys Populaarimusiikkia Vittulanjänkältä, missä alueen kulttuurin ja kielen marginaalisuus sekä tietynlainen 
identiteettiin yhdistyvä alisteisuus käännettiin positiivisella, itseironisella tavalla vitsiksi (Ridanpää 2014a). Vastaavasti musiikin puolella huumorin kautta tunnetuksi ovat tulleet Raj-Raj Band sekä meänkielistä reggaeta esittävä The Meänland. Vastaavasti Pajalassa toimiva radiokanava Meänraatio on vuosittain järjestänyt vitsinkerrontakilpailuja. Viimeisimpänä Ruotsin televisiossa tornionlaaksolaiseen mieheen kohdistuviin stereotypioihin osin terävän ironian avulla pureutuva sarja Bastubaletten on havainnollistanut hyvin, miten alueen asukkaiden identiteetti on hyvin pitkälti sidoksissa huumoriin.

\section{RYHMÄSSÄ NAURAMINEN TUTKIMUSMENETELMÄNÄ}

Vähemmistöidentiteettien tutkimuksessa ryhmäkeskustelua pidetään yleisesti erinomaisena metodina (Booth \& Booth 1996). Ryhmäkeskustelu on varta vasten tiettyä teemaa varten organisoitu tapahtuma, jossa osallistujat saavat äänensä kuuluviin, sanottavansa sanotuksi. Tutkijalle ryhmäkeskustelu, verrattuna perinteisiin henkilöhaastatteluihin, tarjoaa mahdollisuuden tarkkailla jaettujen ja ristiriitaisten näkemysten kirjoa ryhmän sisäisenä vuoropuheluna (Price 2010). Tässä tutkimuksessa käytettävä menetelmä pohjautuu narratiiviseen tutkimukseen, "pienten" kertomusten kuuntelemiseen, pyrkimykseen antaa keskusteluihin osallistuvien kertoa omia tarinoitaan omilla äänillään (ks. Bamberg \& Georgakopoulou 2008; Georgakopoulou 2006; Polkinghorne 1995).

Ryhmäkeskusteluja hyödyntävissä tutkimuksissa on tuotu esiin, kuinka huumori toimii kommunikatiivisena mekanismina, jonka avulla ryhmän yhteenkuuluvuudentunteen perimmäinen olemus saadaan tuotua esiin (ks. Terrion \& Ashforth 2002). Esimerkiksi Lotta Weckström (2011) tekee ruotsalaisten suomalaisuus-käsityksiä käsittelevässä tutkimuksessaan mielenkiintoisen havainnon, kuinka muihin diskursseihin verrattuna keskustelu suomalaisuudesta usein ikään kuin naureskellaan alas, jolloin puheen tapa, naureskelu, kertoo itse asiassa enemmän haastateltavien käsityksistä kuin heidän antamansa vastaukset. Huumoria on myös käytetty tietoisesti tutkimusmetodina herkkäluontoisia asioita käsiteltäessä (Browne 2016). Kertomuksille nauraminen on usein spontaanimpi reaktio ryhmässä henkilöhaastatteluihin verrattuna. Samalla keskustelun osallistujat tarttuvat helpommin kiinni tarinoiden humoristisiin puoliin sekä huumorin rooliin osana tarinoiden sisältöä ja merkitystä. Identiteettien sisällön ja moninaisuuden tutkimuksessa pienten tarinoiden kuuleminen ja ryhmässä nauraminen on monella tapaa käyttökelpoinen metodi, jossa tutkijan tulee kuitenkin pyrkiä osoittamaan herkkyyttä nauramisen useille eri funktioille.

Tämän tutkimuksen aineistona käytetyt ryhmäkeskustelut suoritettiin syyskuun 2015 ja helmikuun 2016 välisenä aikana Haaparannalla, Övertorneålla, Svansteinissa, Korpilombolossa, Aapuassa ja Pajalassa. Keskusteluja järjestettiin yhteensä kahdeksan ja pituudeltaan ne olivat 1-1,5 tunnin mittaisia. Ryhmien koko vaihteli kolmesta yhteentoista henkilöön. Yhteensä osallistujia oli 32, joista naisia 17 ja miehiä 15. Osallistujat tunsivat hyvin toisensa entuudestaan, sillä ryhmät oli tarkoituksella koottu aina tietyn yhden kulttuurisen toimen edustajista. Osallistujat olivat muusikoita, peruskoulun opettajia, päiväkodin opettajia, kirkkotyöntekijöitä, radiotoimittajia sekä erityyppisissä tehtävissä toimivia kulttuurityöntekijöitä. 
Kaikilla haastateltavilla oli läheinen suhde meänkielen suojelemisen puolesta tehtävään kielityöhön, joten ryhmäkeskustelut voidaan myös nähdä eräänlaisina asiantuntijahaastatteluina.

Haastatteluihin kutsutut kulttuuritoimijat nähdään informantteina, joilla on laaja käsitys alueen kulttuuriperinteestä ja -historiasta sekä kattavat kontaktiverkostot eri ihmisryhmiin, joiden kanssa he ovat päivittäin tekemisissä. Tutkimukseen osallistuneiden inmisten rajaaminen kulttuuritoimijoihin pitää luonnollisesti sisällään riskin, että tietyt "kansan kerrokset" jäävät äänettömiksi. Myös välikäden kautta tapahtuvaan kertomusten siirtämiseen liittyy tietynlainen autenttisuuden katoamisen riski. Kulttuuritoimijoita ei tule kuitenkaan ymmärtää tiukasti lokeroituna, koherenttina ryhmänä. Toimijat kertovat esimerkiksi tarinoita hirvijahdista omien kokemusten kautta. On selvää, että mikäli haastatteluihin olisi valittu kohderyhmät eri perusteilla, olisivat tutkimustuloksetkin voineet olla erilaisia. Tässä yhteydessä on kuitenkin keskeistä painottaa sitä, ettei tutkimuksen tavoite ole päästä kiinni paikallisten asukkaiden arkeen sellaisenaan vaan ennen kaikkea alueen jaettuihin kertomuksiin.

Keskustelutapahtuma oli identiteettikertomus itsessään, eräänlainen performanssi, jossa ryhmän jäsenet juonellistivat omaa identiteettiään vuorovaikutteisesti toisilleen. Pyrkimykseni tutkijana oli tarkkailla identiteetin ja huumorin suhdetta kahdella eri tasolla. Ennen keskustelujen käynnistymistä kerroin lyhyehkösti oman tutkimukseni keskeisen idean. Näin ollen alueelle tyypillisestä huumorista muodostui yksi keskustelun temaattinen aihe. Keskustelujen aikana ja nauhoituksia analysoidessa kiinnitin erityistä huomiota siihen, kuinka keskustelijat käyttivät huumorin eri muotoja ja naurua osana tarinankerrontaa. Keskustelu kävi spontaanisti ja tutkijana tarkoitukseni olikin pysyä mahdollisimman passiivisessa roolissa. Jokaista keskustelua varten oli erikseen laadittu erillinen aiherunko, jossa mukana oli juuri kyseiselle ryhmälle kohdistettuja temaattisia kysymyksiä sekä lisäksi kaikille ryhmille suunnattuja yhteisiä kysymyksiä, kuten:

- mitä mieltä olette meänkielen kehittämiseen liittyvästä toiminnasta?

- miten kielikysymys nousee esiin tai tulee ottaa huomioon teidän toiminnassa?

- ovatko tornionlaaksolaiset inmiset jollakin tavalla erilaisia suomalaisiin tai eteläruotsalaisiin inmisiin verrattuna?

- onko tornionlaaksolainen kulttuuri ja elämä jollakin tavalla erilaisia Suomeen tai Etelä-Ruotsiin verrattuna?

- mitä mieltä olette paikallisista "humoristeista" (Niemi, Raj-Raj Band, ...)?

Kysymyksenasettelut ovat korostetusti tutkimusasetelman näkökulmasta laadittuja, ja näin ollen selvästi johdattelevia. Onkin tärkeää korostaa sitä, että yllä mainituista teemoista keskustelu käynnistyi lähes poikkeuksetta spontaanisti, ilman että tutkijan tarvitsi niitä erikseen nostaa esiin. Käytännössä tutkijan rooliksi muodostui tarinoiden kuuntelu ilman aktiivista osallistumista varsinaiseen 
keskusteluun. Ryhmien jäseniä ei varta vasten pyydetty kertomaan tarinoita, vaan tarinankerronta tuli osaksi keskustelua automaattisesti. Osa tarinoista oli haastateltavien itsensä, heidän tuttaviensa tai sukulaisiensa kokemia tapahtumia, osa taas useissa ryhmäkeskusteluissa toistuvia kertomuksia, eräänlaisia alueellisia kertomuksia, jotka ovat tapahtuneet "jollekin, jossakin, joskus". Käsittelen tässä keskustelujen jäseniä anonyymeinä, eikä heidän toimintaympäristöään määritellä erikseen. Esimerkeissä mainitut nimet ovat muunnettuja.

\section{MEÄNKIELI: HÄRSKIÄ JA RANKKAA}

Kun huumori ymmärretään inmisten tilallisen identiteetin määrittäjänä, on pohjalla usein ajatus siitä, että inmisten, tässä tapauksessa kielellisen vähemmistön, huumorintaju on erilaista kuin muualla. Esimerkiksi kansainvälisesti tarkasteltuna suomalainen huumori näyttäytyy raskaana, synkkänä, junttimaisena, suoraviivaisena, outona ja itseironisena (Luostarinen 1997). Tiettyjä yhtymäkohtia suomalaisen ja meänkielisen huumorin väliltä voidaan löytää, mutta usean keskustelun aikana osallistujat halusivat erityisesti korostaa sitä, kuinka meänkielinen huumori ja huumorintaju poikkeavat sekä suomalaisesta että ruotsalaisesta huumorista. Samoin erilaiset käsitykset siitä, mikä on hauskaa ja mikä ei, muodostavat hauskoja tilanteita jo itsessään, joista myöhemmin muotoutuu suusta suuhun siirtyviä kertomuksia. Lisäksi erilaiset käsitykset siitä, mikä on normaalia ja hyväksyttyä kieltä, on aiheuttanut tilanteita, joista myöhemmin on syntynyt hauskoja tarinoita, jotka erityisellä tavalla luonnehtivat meänkielistä narratiivista identiteettiä.

Yhtenä keskeisimpänä meänkielistä huumoria luonnehtivana piirteenä nähtiin sen karkeus ja rivous. Pajalalaisen Mikael Niemen jo klassikoksi muodostunut Populaarimusiikkia Vittulajänkältä on tietyllä tapaa muodostunut tämän näkemyksen perustaksi. Arkisen kommunikaation ja kertomusten rivoudesta ollaan jopa tietyllä tapaa ylpeitä. Korpilombololainen mies kertoi kaskun siitä, kuinka haastavaa heidän oli saada paikkakunnalle muuttanut pappi kiroamaan:

Se oli niinko tuolla päätettiin että mukava kuulla ko kuinka pappi ko se, me aattelimma että me hääymmä saaha se kiroahmaan, papin. Me otimma skuutterilla kevväällä, niin se lähti meän matkaan. Se istu kelkhaan ja me vasiten ajoimma kiinni skuutterin sielä jänkhällä ja kirosimma oikein siinä. Ja ei pappi. Se viimeiseks sano, että "det samma, det samma".

\section{(Ryhmäkeskustelu 4.)}

Tarina siitä, kuinka ruotsalainen pappi ei yksinkertaisesti suostu kiroamaan, kerrotaan toisaalta kertojalle sattuneena tositapahtumana, toisaalta tarinana, jonka voisi julkaista sellaisenaan vitsikirjassa. Kaskun taustalla on yleinen ruotsalaisessa populaarikulttuurissa toistuva stereotypia Pohjois-Ruotsin asukkaiden sivistymättömyydestä (Eriksson 2010), joka tässä käännetään itsetietoisesti paitsi naurunaiheeksi, myös tietynlaiseksi ylpeydenaiheeksi. Paikallisen huumorin rivoutta heijastetaan suhteessa eteläruotsalaiseen "ylihienostuneeseen" kulttuuriin, mutta toisaalta vertailukohdaksi asettuvat usein myös suomalaiset ja heidän käsityksensä siitä, millaista arjen kommunikaation tulisi olla. Vaikka rivous on voimakkaasti läsnä myös suomalaisessa huumorissa, meänkieliset itse tekevät selvän eron siinä, 
kuinka karkeaa kieltä käytetään nimenomaan arjen tilanteissa Suomessa eri tavalla ja kuinka tämän johdosta aiheutuu tilanteita, joita voidaan pitää omalla tavallaan koomisina. Suomessa syntynyt, myöhemmin Ruotsiin muuttanut, mutta itsensä enemmänkin suomalaiseksi identifioiva nainen luonnehtii paikallista kielenkäyttöä:

[t]äällähän puhutaan Ruottin puolella näin että, jos nyt saapi rumia sanoja khäyttää, että mie lähen kuselle ja paskhalle, niin Suomessahan ei, sehän on rumia sanoja. Mutta täällä Tornionjokilaaksossa ne on siis tavallisia sanojah, vanhan ajan sanoja ja meille suomalaisille se tuntuu, että voi kamala paikka, miten tuo inminen voi puhua tuolla tavalla.

(Ryhmäkeskustelu 2.)

Naisen luonnehdinta tornionlaaksolaisesta kielenkäytöstä päättyy äänekkääseen nauruun, johon vanhempi nainen jatkaa: "Mie ko sanon sulle, että mie kusen tuonne - (sie sanot:) "tsss, tsss, tsss" - mie sanon sulle, et ei se auta, että mie aion kuitenki lähtä kuselle." Kyse on tietynlaisesta tilanteeseen liittyvästä ironiasta, jonka nähdään olevan hauskaa nimenomaan meänkieltä puhuvien näkökulmasta. Perinteiseen kommunikatiiviseen ironiaan verrattuna tilanteeseen liittyvässä ironiassa ei huumori synny kielenkäyttöön sisältyvissä ristiriidoissa, vaan keskustelutilanne on itsessään ironinen, kun sitä tarkkaillaan ulkopuolelta (Szerszynski 2007, 341). Tässä tapauksessa ulkopuolisena tarkkailijana, naurajana, on meänkielinen, jolle suomalaisen ymmärtämättömyys näyttäytyy ironisella tavalla huvittavana. Edellisen vanhemman naisen lyhyehkön lausahduksen perusidea toistuu useissa vastaavanlaisissa kertomuksissa, joissa tarinan kaava ja vitsin kärki on käytännössä sama. Tarinat siitä, kuinka suomalaisten mielestä karkeat voimasanat ovat meänkielisille tavallisia arjen sanoja, ja kuinka niiden korvaaminen on mahdotonta, saa useita variaatioita eri kertomuksissa. Esimerkiksi övertorneålainen mies kertoo vastaavanlaisen tarinan omasta menneisyydestään:

Mie muistan aina ku me saimma ensimmäise lapsen ja olimma sitten Suomessa kylässä yhessä paikkaa ja (...) mie sanoin, että poika on paskhantanu houssuun, että otappa uusi blöja, sanoin tuota vaimolle. Sitten siinä istui yksi, joka: "Herra Jeesus, että sanotteks te noin että on paskhantanu housuun"? No tietysti, että paskanuhan se on. "No ei sitä sanota lapsesta, että se on paskhantanu houssuun". Mie olin aivan että, enhän mie sanonu sen kummempaa, sehän oli paskhantanu houssuun. Sehän se sano hienommasti: "täytyy sanoa, että kakata tai jotakin semmosta", mutta minusta se ei ollu kummaa.

(Ryhmäkeskustelu 6.)

Tietoisuus siitä, että suomalaisessa kontekstissa karkeana pidettävä kieli, voimasanat ja kiroaminen ovat luonnollinen osa meänkielistä arjen kommunikaatiota, asettuu identiteettiä määritteleväksi tekijäksi. Raja-alueella asuttaessa meänkielisten ja suomenkielisten kohtaaminen on arkipäivää, mutta välillä kielelliset erot aiheuttavat koomisia tilanteita, jotka jäävät osaksi inmisten kertomuksia, osaksi heidän narratiivista identiteettiään. Samalla käsitys erosta meänkielen ja suomen kielen samoin kuin meänkielisten ja suomenkielisten ihmisten välillä vahvistuu. Yhdessä keskustelussa Suomessa syntynyt ja Ruotsiin muuttanut, itsensä enemmän suomenkieliseksi identifioiva nainen kertoi esimerkin siitä, kuinka kielenkäyttöön 
liittyvät haasteet suomalaisten ja meänkielisten kommunikaatiossa voivat aiheuttaa koomisia tilanteita:

Miun miehen sisko, se tuota ossaa kans meänkieltä tietenki ja soon kauheen rohkee, se puhhuu niinkö joka paikassa. (...) Soli Suomeen menny pesemään piiliä, niinkö tämmösheen mihin ajethaan sisälle. Sitten hän meni ja hän aatteli että ottaa niinkö sen auton pohjan kanssa että sekin pestään, niinkö se alaosa. Sitten hän meni sinne sisälle, sinne makhiin ja sano et hän haluaa pestä piilin - joo-o, ei se mithään - hän mietti, että just det, että sitte mie haluan piilin pesun ja sitten mie haluan alapään pesun kans.

(Ryhmäkeskustelu 6.)

Jokseenkin kaksimielinen kasku päättyy naurunremakkaan, mihin keskusteluun osallistunut mieshenkilö lisää: "Jos soon tärkheää niin ei muutako levittää polvet ja antaa harjan käyä." Tarinaa kertonut nainen selittää tapahtuman loppuun:

Mutta niilä oli ollu kuulema rikki sitten se millä pestään se alaosa. Maria sano, että hän näki ko se katto se poika, (...), ja sano että, tai mies, sano että: "rouva, hyvä rouva, se ei onnistu nyt, koska meillä on tanko rikki."

(Ryhmäkeskustelu 6.)

Ja nauru jatkuu. Tarina on jälleen kerrottu vitsinä, jota sävyttää (kirjaimellisesti) alapäähuumori. Vaikka tarina itsessään ei varsinaisesti havainnollista sitä, kuinka meänkieli on rivoa, niin se, kuinka tarina kerrotaan kyseisessä tilanteessa ja ennen kaikkea kuinka keskusteluun osallistuvat henkilöt kertomukseen reagoivat, kertoo paljon meänkielisestä huumorintajusta. Samalla hauskan tarinan ja yhdessä nauramisen kautta muotoutuu ja uusiutuu kategorinen ero suomenkielisten ja meänkielisten välille.

Kirosanat ja kiroaminen nähdään luonnollisena osana meänkielisten arkea, mutta tämän lisäksi kirosanojen rooli osana paikannimistöä on oma mielenkiintoinen ilmiönsä. Useissa alueen paikkojen nimissä, lähinnä arkipuheessa käytetyissä lempinimissä, on mukana karkeutta ja rivoutta. Mikael Niemen Populaarimusiikkia Vittulajänkältä ja teoksen tapahtumien keskuspaikka Pajalan Vittula on klassinen esimerkki, mutta vastaavanlaisia paikannimiä löytyy muualtakin Tornionlaaksosta. Haastateltavat korostavat, kuinka paikannimet kuten Ruumisniemi, Paskala ja Pillujoki kuulostavat suomalaiseen korvaan karkeilta, mutta kuinka paikallisille asukkaille kyse on normaalista, luonnollisesta kielestä. Olennaista on kuitenkin ymmärtää, kuinka karkeat ja rivot paikannimet omalla tavallaan myös pitävät yllä paikallista folklorea, erityisesti kun jokaisen paikannimen takana on oma uniikki tarinansa. Ohtanajärveläinen nainen kertoo tarinan siitä, kuinka Pillujoki on saanut nimensä:

Börjehän se selitti siittä, se sano ko hää on syntyny sielä. Mie kysyin, että minkä vuoksi on pantu nuin ryöttä nimi, että Pillujoki, mutta hää on, että siihen on aika luonnoline selitys siihe, että ennenhän on uitettu kohta joka pienen ojan ja joen myöten. Sillon käytethin vettä, että saathiin kaikki puut minne haluthin, porrit, ja se sano sitten että justiinsa sitä Pillujokea, että siinä on vaimotki eli naisihmiset 
olheet myötä uitossa ja siksi soon tullu se nimi siihen. Että se ei ollu muuten niin tavallista.

(Ryhmäkeskustelu 4.)

Paikannimissä mukana oleva karkeus nähdään eräänlaisena paikallista historiaa ja identiteettiä luonnehtivana tekijänä. Useissa haastatteluissa painotettiin erikseen sitä, kuinka paikallisella tasolla työnteko on perinteisesti ollut jyrkästi sukupuolittunutta: miesten työt ja naisten työt on erotettu selkeästi toisistaan. Edellisen kertojan mukaan tukinuitto on aina ollut miesten työtä, joten tukinuittoa tekevä nainen on paikallinen erikoisuus, anomalia. Kun naisten tukinuitosta tulee paikallinen käytäntö, kuten Rantajärvellä on tapahtunut, syntyy uusi tarina ja paikalle uusi nimi, Pillujoki. Yksittäisillä kertomuksilla on siis merkittävä rooli tilan narratiivisen identiteetin muotoutumisen ja sen ylläpitämisen kannalta. Toinen vastaava tarina kertoo siitä, miksi Ruotsin Pellossa sijaitsevaa Valkeakoskea on alettu kutsumaan Paskalaksi:

- Hevosilla kuljethin Mataringista, tuli passeli väli topata siihen ja ne hevoset sait rehuja ja sithän ne paskansit samala. Tuli kanssa semmonen leikkinimi, mutta kuitenki se on käytetty ja se on myös Ylipaskalakin olemassa. Paskala ja Ylipaskala.

- Joillakin oli kovalla vatta.

- Mutta sitten kyläläiset itte pihit pahana, että he eivät halua sanoa, että ne asuvat Paskalassa.

- Joo se on ussein ollu sillä lailla.

- Mie tiiän että nyt jotkut (...) on muuttunu, (...) ja on ylpeitä siittä sen histuuriasta, että ei se tarkota että ne on paskasia inmisiä.

(Ryhmäkeskustelu 4.)

Kuten tarinan kertonut nainen mainitsee, karkealta kuulostavat leikkimieliset paikannimet voivat toki aiheuttaa pahennustakin, erityisesti paikallisten keskuudessa, mutta toisaalta karkea paikannimi ja sen taustalla oleva historia voidaan tarinan avulla kääntää ylpeydenaiheeksi. Karkeus on toisaalta luonnollista, mutta toisaalta leikkimielistä, sillä lähes poikkeuksetta kaikki meänkieliset ovat tietoisia siitä, miltä "heidän", eli suomalaisten korvaan nämä paikannimet kuulostavat. Ottaen huomioon suomalaisuuteen yhdistetyt stereotypiat, tämä "suomalaisen siveyden" korostuminen tuntuu kieltämättä erikoiselta. Voi olla, etteivät haastateltavat tienneet, että karkeita paikannimiä löytyy toki Suomestakin: I/ta-Sanomat uutisoi 17.8.2015, kuinka Suomesta löytyy yli 1600 paikannimeä, joita voidaan pitää poikkeuksellisen härskeinä, kuten Laukaan Pimppiniemi, Lohjan Ämmänperse ja Heinolan Kulliluoto (Lehtinen \& Markkola 2015). Ero syntyy kuitenkin siinä, etteivät meänkieliset karkeat paikannimet ole paikallisille asukkaille karkeita, vaan tavallista arjen kieltä. 


\section{MeäNKIELI - haUSKA KIELI?}

Sekä kieliä että murteita pidetään usein kontekstisidonnaisina: tietyn aihepiirin käsittely konventiosta poikkeavalla puhetavalla ei ole asianmukaista, ja mikäli näin kuitenkin pääsee käymään, asettuu puhuja tietyllä tapaa naurunalaiseksi. Tästä hyvänä esimerkkinä toimivat murteilla kirjoitetut sarjakuvat. Syksyllä 1997 ilmestyi Suomessa ensimmäinen murteella kirjoitettu sarjakuva, savvoo viäntänä Asterix ja vastaavasti Aku Ankka hauskuutti lukijoitaan vuonna 2015 kahdellatoista eri suomen murteella. René Goscinnyn luoma ranskalainen Asterix voi puhua sujuvasti suomea kirja-/puhekielellä, mutta savon murteeksi kirjoitettuna kertomus muuttuu automaattisesti vitsiksi. Meänkielessä on paljon vastaavanlaisia kielen käyttöön liittyviä tilannerajoitteita. Vaikka meänkieli onkin saanut virallisen vähemmistökielen statuksen, käytännössä se ei kuitenkaan sovi virallisten asioiden hoitamiseen. Esimerkiksi yhdessä keskustelussa kaksi övertorneålaista naista nosti esiin, kuinka Luulajassa meänkielellä pidetty jumalanpalvelus koettiin toisaalta kotoisena, mutta toisaalta jollakin tapaa erikoisena ja koomisena:

- Kaikki tapahtumat olit meänkielellä. Mie hääyn kyllä sanoa, että mitä enämpi mie olen ollut matkassa semmosessa niin sitä mukavampi se minusta on. Jotenki se tullee niinko lähelle itteä ko sen kuullee sillä omalla murtheella, että niinko pappikin puhhuu semmosta ko mitä me puhumme ja me lauloimma sitten niitä tuttuja virsiä meänkielellä. Ei se ollu yhtään hullumpaa. (...)

- Oli niin mukava kuulla. Se oli aivan erilaista.

- Mutta kyllä ensimmäisiä kertoja, kyllä minua vähän pakkas se niinko naurathaa. Jotkut semmoset tutut Raamatun tapahtumat kerrottuna meänkielellä, niin siinä tulhee vähän semmonen että, oi!

- Kyllä me sielä vähän hilisimmä. Kyllähän se oli vähän hauskaa.

- Kyllä! Pakkas vähän meitä naurattamhaan.

(Ryhmäkeskustelu 7.)

Meänkieltä pidetään kontekstisidonnaisena puhekielenä. Edellisen esimerkin naisten mukaan vakavista asioista puhuminen meänkielellä ei ole luontevaa. Myös Ylitorniolta kotoisin olevan Rosa Liksomin alkutuotannon tulkinnoissa on mainittu erikseen, kuinka hauska, mukava ja hellyttävä kieli meänkieli on (ks. Hurme 1996; Kantokorpi 1997). Keskustelujen aikana nousi esiin useita kuvauksia siitä, kuinka nimenomaan suomalaiseen korvaan meänkieli kuulostaa jo sellaisenaan hauskalta:

- Mie Luleåssakin olin töissä, ko suomalainen vaimo oli samassa työssä. Se sano että "voi sinua on niin hauska kuunnella, sie puhut aivan ko minun vanha mummu". (Ryhmäkeskustelu 2.)

- Molen ollu turistihommissa ennen ja työskennelly vähäsen niinkö ophaana Luulajassa. Mulla oli monta suomalaista porukkaa. Mie muistan esimerkiksi yhen porukan joka sano mulle, että "oi tämä oli niin ihana tämä retki". Mie olin et, ui mie olen tehny hyvän työn. "Se on se sinun kieli, mä olen vain sitä istunu ja kuullu". Se ei 
tietäny missä me olimme ollutkhaan. Se oli vaan kuunnellu minun kieltä koko ajan. Ja muistellu hänen lapsuuttaan. (Ryhmäkeskustelu 8.)

Huumorilla on merkittävä rooli ryhmän narratiivisen identiteetin muotoutumisessa, mutta toisaalta identiteetin assosioiminen inmisten humoristisuuteen voidaan kokea myös loukkaavana. Laura Arola (2006) on tuonut nuorten ja vähemmistökielten välistä suhdetta tarkastelevassa tutkimuksessaan esiin, kuinka Ruotsin Tornionlaaksossa ihmisten suhde kieleen on asenteellinen. Kuten Arola $(2006,16)$ toteaa, kieliasennekysymys on pitkälti myös identiteettiin ja ryhmäsolidaarisuuteen liittyvä kysymys, joka meänkieltä puhuvalla alueella on varsin moniulotteinen ja monimutkainenkin kysymys. Keskusteluissa meänkielen koomisuus nähtiin usein eräänlaiseksi ylpeydenaiheeksi. Toisaalta, jos kieli merkitsee inmisille heidän identiteettinsä kulmakiveä, on myös mahdollista, että ajatus kielen sisäsyntyisestä hauskuudesta voidaan kokea myös loukkaavana. Pajalalainen mies kertoi omasta kokemuksestaan:

Yks asia minkä mie oon huomana, että monihan tykkää Suomessa, että met olema humoristia aivan tämän kielen takia, koska kieli tuntuu niin hauskalta ja kireältä ja siinä on huumoria niinkö suomalaisen kuvassa. Tämä murre. Ja murtheit on käytetty siinä tarkotuksessa, että sitä on niinkö vähän naurettu ja pilkattu ja täällähän soon kieli, et me emme niinkö itte huomaa sitä et molisimma humoristia sen kielen takia, että täällähän soon se kieli mitä käytethään ja suomi on niinku sitten se mihinkä me vertaamme ja vieras kieli meille. Ossaamme enemmän tai vähemän. Mutta mie olen huommannu sen Suomessa, että tämmöse reaksuunin saattaa saaha välistä. (...) Mie olin kerran Kolarissa - siittä on aikoja - mie pii'in jonkulaise fööretalkin, jonku luennon siellä, jostaki asiasta täällä. Soli kansalaisopisto sielä ja sielä oli paljon sakhia. Se oli pian satakunta ihmistä sielä salissa ja mie kattoin että net muljuili koko ajan ja mie puhun vakavista asioista! Että onko mulla housunpellit auki? Mikäh mullon tässä vikana? Ja jälkhiin sain kuulla mist oli kysymys. (Ryhmäkeskustelu 3.)

Kuten kaikkia murteita - savoa tai smålannin murretta - voidaan käyttää hauskuuttamisen apuvälineinä, niin paikallisille asukkaille kyse on usein kuitenkin tunnekielestä. Edellinen kertomus on esimerkki siitä, kuinka naureskelu toimii meidän ja heidän välisen kategorisen erottelun välineenä. Meänkielelle naurettaessa suomen kielen ja meänkielen välinen ero tulee alleviivatuksi, mutta jos nauraja itse on meänkielinen, ei pilkkaavaa ulottuvuutta välttämättä nähdä olevan mukana. Eräässä keskustelussa kaksi opettajaa kävi läpi sitä, kuinka meänkieli on sellaisenaan hauskaa juuri meänkielisille itselleen:

- Mie tykhään se on hauskaa. Välistä saa niitä sanoja saattaa kääntää, tullee välistä hölynpölyä. Vet du?

- Ethän sie kuule kuinka itte puhut, muttako sie kuulet toisen, herregud. Kyllä se on aika hauskaa.

- Juu, jag tycker det är roligt, joo mie tykhään se on mukavaa, että ko sitä saattaa vaikka slänga liten så där, skämta åt nån, eikä se tule niin tyhmästi sitten. Välistä ko sen haluaa niinko säga skämt åt nån, vi säger att det finns snälla ord också, mutta sen saattaa antaa niinko jollakin mukavalla sanalla. Se toinen ymmärtää. Ruottiksi mie pian sanon niin kovasti, että toinen pittää pahaksi.

(Ryhmäkeskustelu 5.) 
Tässä yhteydessä meänkielen hauskuuden nähdään olevaan kielen käyttömukavuudessa, siinä kuinka meänkielellä puhuminen ei ole yhtä "vakavaa" kuin ruotsiksi puhuminen. Lisäksi meänkielelle ominainen tapa käyttää puheessa ruotsia ja suomea sekaisin nähdään usein omalla tavallaan hauskana kommunikaation muotona. Vastaavasti toisessa keskustelussa käytiin läpi sitä, kuinka paljon perheet itse käyttävät arjessaan meänkieltä ja kuinka hyvin heidän lapsensa sitä osaavat. Övertorneålainen nainen kertoi omista lapsistaan:

Ruottia varmasti lapset. Mutta nehän olit fammun ja faffan kaa - mie muistan kun Göran oli pikkunen - siel naapurit taalaa suomea. (...) Molimma jossakin autolla liikheellä, se katto että: "titta, en poro!" (Ryhmäkeskustelu 6.)

Tämäkin lyhyt vitsinomainen kertomus saa ryhmässä aikaan äänekkään naurunremakan. Tornionlaaksossa on kahden vuosisadan historia suomen/meänkielen ja ruotsin kielen yhdistämisestä. Ruotsin ja meänkielen sotkeminen on paikallisten, johonkin suuntaan enemmän tai vähemmän kielipuolisten asukkaiden, arkea ja varsin yleistä on, että kolmella kielellä sekaisin puhuminen herättää paitsi kuulijoissa, myös itse puhujissa hilpeyttä. Tähän liittyen useissa keskusteluissa nousi esiin se, kuinka kielikolarit suomen kielen ja meänkielen välillä ovat itsessään hauskoja tai aiheuttaneet hauskoja tilanteita:

\begin{abstract}
Niitähän on paljon semmosia sanoja niinkö, jokka on suomenkielessä ja meänkielessä erit. Yks sana on "pyörtyä". Suomessahan se on niinkö, "sie pyörryt" ja meänkielessä se on "eksyä". (...) Molin vasta alkanut Svenin kanssa seurustelehmaan ja olimma jossakin kylässä ja se selitti se mies siinä että hui tuo hänen vaimo, se on aivan mahoton, eihän sen kanssa voi lähteä mittään, se pyörtyy. Yksin ollethikkaan ei ku se pyörtyy, ja kartanolle ku se mennee niin se pyörtyy. Kämpän taakse niin se pyörtyy. Ja mie aattelin, että on se vain veikko. Ennen ku se sitten selvis, että sehän eksy. Ja sitten taas suomessa "menehtyä". Täällä sanothaan että menehtyy, niin soon pyörtymistä, meänkielessä menehtyminen ja suomessa se on kuollut. Ja siinäkin oli kerran ku joku, ku soli sairas (...), että "no, mites sille kävi?" "Ei se ko menehty vain." (Ryhmäkeskustelu 6.)
\end{abstract}

Vaikka joillekin meänkielen hauskuus on hellyttävä asia, liittyy aiheeseen myös katkeruutta, joka palautuu useimmiten suomen kielen ja meänkielen vastakkainasetteluun. Kielityön parissa työskenteleville inmisille ajatus meänkielen koomisuudesta voi tuntua loukkaavalta, mutta toisaalta yksi meänkieltä koulussa opettava opettaja korosti myös sitä, kuinka tärkeää on, että meänkielen oppiminen mielletään hauskaksi kokemukseksi. Tässä korostuukin hyvin huumorin funktioiden moninaisuus: huumorilla voidaan loukata, ivata, pilkata, miellyttää, helliä, kouluttaa ja sivistää ilman että nämä funktiot olisivat toisiaan pois sulkevia. Useimmiten kyse onkin enemmän tulkitsijan omasta näkökulmasta ja huumorintajusta kuin huumorin tyylistä ja sisällöstä itsessään.

\title{
ITSETUNTO JA ITSEIRONIA
}

Meänkielen ja meänkielisen kulttuurin revitalisaation myötä paikallisten asukkaiden suhtautuminen omaan marginaalisuuteen, kuten suomalaisiin sukujuuriin liitettyihin stereotypioihin, on selvästi muuttunut. Huumorin yhteys asukkaiden tietoisuuteen omasta marginaalisuudestaan näkyy kahdella, osin päällekkäisellä tavalla. 
Ensinnäkin, oma vähemmistöasema osana ruotsalaista yhteiskuntaa käännetään itseironiaksi, jossa omalle alueelliselle syrjäytyneisyydelle osataan nauraa, hieman samalla tyylillä kuin Mikael Niemi teki ironiaa alueen identiteetin surkeudesta (ks. Ridanpää 2014a). Niemen tuottamasta identiteettikuvasta ollaan ylpeitä jopa niin pitkälle, että alueen marginaalisuus on käännetty paikallisessa turismissa vetovoimatekijäksi (Ridanpää 2011). Alueen asukkaat ovat luonnollisesti aina tiedostaneet asuvansa kaukana etelän keskuksista, mutta toisaalta omalle syrjässä olemisella osataan naureskellakin:

Minä olen kuulu monta kertaa, ko noon etelämpää tulheet tänne ja mainohneet ja soittahneetkin, että no "Korpilombolo, että jaa, että onkos se olemassa semmonen paikka?" Että ei, he ol uskohneet et se on vain semmonen mitä sanotaan, että hehän on pölättäny hänen kläppiä sillä, että jos ette tule ihmisten laihin niin hä lähettää teät Korpilombohloon. (Ryhmäkeskustelu 4.)

Korpilombololaisen naisen naurunremakan synnyttäneestä kuvauksesta käy hyvin ilmi, kuinka eteläruotsalaisilla saattaa usein olla vääristynyt, omalla tavallaan mystifioitunut käsitys Pohjois-Ruotsista, tässä tapauksessa yhdestä pienestä 800 asukkaan kylästä. Vaikka etelän asukkaiden tietämättömyys voidaan nähdä myös loukkaavana, käännetään se tässäkin vitsiksi. Kyse on tietynlaisesta paikallisella tasolla ilmenevästä kiistämisen kulttuurista. Kiistämisen kulttuurilla viitataan sellaisiin kerronnan tapoihin ja sanontoihin, joiden kautta tietyssä valta-asetelmassa heikompana osapuolena oleva, niin sanottu "alistettu kansa" kyseenalaistaa valtaa pitävän eliitin esittämän virallisen totuuden, toistamalla (sarkasmilla sävytettynä) hegemonista fraseologiaa (Knuuttila 1992, 71-77). Mielenkiintoista edellisessä humoristisessa kertomuksessa on kuitenkin se, kuinka kuulija voi halutessaan nauraa niin Korpilombololle kuin etelän asukkaiden vääristyneille käsityksille, tai molemmille samanaikaisesti. Vastaavasti toinen tapa reagoida alueen marginaalisuuteen on pyrkiä puolustamaan omaa kieltä, kulttuuria ja erilaisuutta tietynlaisen uhon avulla, missä sarkastista huumoria käytetään retorisena apuvälineenä. Haaparannalta alun perin kotoisin oleva mies kertoo omista kokemuksistaan:

Mie olin lääninhallituksessa töissä tuossa kaheksankymmentäluvun alussa, seittemänkymmentäluvun lopussa, ja miun tehtävä oli käyä kouluttaa kuntia kunnan rakentamisessa, että ottaa erilaisia vaaratekijöitä huomioon ko rakentaa taaja-asutusta ja näin ja mulla oli sitten mun johtaja, ruottinkielinen nainen mukana ja se kuunteli minun esityksen siinä ja se sannoo mulle ko met tulemma kotia, että "herran jestas Pär, että kyllä sie häät korjata tuon ruottinkielen, että kaikki kuulevan mistä sie olet kotosin. Että sullon semmone murre, että sie häät työskennellä poies tuon murtheen, että kaikin kuulevan mistä sie olet kotosin." Ja mulla pisti nokhaan, mie sanoin että: "juu justhiin kyllä sie olet aivan oikeessa. Eikä kukhaan tiedä mistä sie olet, ko sie puhut." Se meni suu kiinni että klopsahti. (Ryhmäkeskustelu 8.)

Tässä tapauksessa kulttuurista marginaalisuutta määrittelevänä tekijänä ei ole meänkieli, vaan meänkieltä äidinkielenään puhuvan tornionlaaksolaisen ruotsin aksentti, "väärin" puhuttu ruotsin kieli. Mikael Niemi kirjoittaa: "Me mursimme suomalaisittain olematta suomalaisia, me mursimme ruotsalaisittain olematta ruotsalaisia. Me emme olleet mitään." (Niemi 2001, 54.) Kiistämisen kulttuurissa on kyse syrjäytetyn itsetietoisesta itsepuolustuksesta, mihin on helppoa myös projisoida sankaruuden leima (Knuuttila 1992, 75). Edellisessä esimerkissä suomalaisittain murtaminen 
käännetään alueen identiteettiä määritteleväksi ominaispiirteeksi, ylpeydenaiheeksi, mikä osoitetaan laittamalla ruotsia puhuvalle hienostelevalle ummikolle jauhot suuhun. Lisäksi kertomuksessa on mukana stereotyyppinen vastakkainasettelu pohjoisen karskin miehen ja etelän "fiinin" naisen välillä. Kiistämisen kulttuurille ominaisesti kertoja on tietoinen omasta alempiarvoisuudestaan, mutta huumorin, tässä tapauksessa sarkasmin avulla alisteisuudeksi tulkittava erilaisuus käännetään kertomuksessa voimavaraksi ja alistetun vähemmistön sankaruudeksi.

Kerrottua tarinaa ei kuitenkaan seurannut naurunremakka, vaan paremminkin eräänlainen "hiljainen nauru", josta huokui se, kuinka vakavasta asiasta loppujen lopuksi oli kyse. Meänkielen sosiaalinen asema ja sen alueellinen historia on arka aihe. Ennen kielen ja kulttuurin revitalisaation käynnistymistä meänkieli oli käytännössä lähes kahden vuosisadan ajan alistettu kieli, väärä kieli, jonka käyttäminen 1900-luvun alusta 1960-luvulle asti oli esimerkiksi kouluissa kiellettyä. Terminologisessa mielessä meänkieli, "meidän pienen vähemmistön oma kieli", jo itsessään kiteyttää hyvin sen mitä kiistämisen kulttuuri Ruotsin puoleisessa Tornionlaaksossa käytännössä tarkoittaa. Toisaalta meänkielen aseman vahvistuminen osoittaa, että vähemmistötyö on tuottanut tulosta. Tänä päivänä syntyykin helposti hauskoja tarinoita siitä, kuinka juuri ruotsin kieli on väärä kieli tietyissä tilanteissa. Kuten eräs nainen kertoo, esimerkiksi metsästykseen osallistumisen ehtona on meänkielen jonkinasteinen hallinta, ja ummikoiden kömmähdyksiä muistellaankin jälkikäteen:

Bergin Annehan selitti siittä, että ne olit pyythäneet hirviä koko päivän ja sitten se jahtijohtaja sitten sano että nyt lähethiin kotia. Sano vain siinä raatiossa ja otaksu että kaikki ymmärsi että mitä se sano, ko se sano meänkieleksi. No se yks nuori vaimo soittaa sille, että missä hänen mies on ko hän ei ole vielhäkään tullu kotia. Se oli ummikko. No se oli jääny sinne passille istumhan, ko se ei ollu käsittäny mitä se sano. Että lähethään kotia. Mutta kyllä se eli, eihän se kuollu sinne. Kyllä sitä pärjää, jääpi elhoon, mutta paljon sitä jääpi vailleki jos ei kieltä ymmärrä. Kyllähän se niin on.

(Ryhmäkeskustelu 4.)

Kun meänkielen hallinta nähdään resurssina, voimavarana, jota ilman tietyissä arjen käytännöissä on mahdoton pärjätä, kääntyy myös kulttuurisen ja sosiaalisen marginaalisuuden historia eräänlaiseksi ylpeyden aiheeksi. Useissa keskusteluissa kuitenkin nousi esiin, kuinka paikalliset asukkaat ja haastateltavat itsekin katuvat sitä, että he ovat päämäärähakuisesti pyrkineet välttämään meänkielen opettamista lapsilleen. Vaikka ruotsalaisessa yhteiskunnassa eteneminen ei edellytä meänkielen hallintaa, niin paikallisella tasolla meänkieli nähdään resurssiksi, jota ilman arjen pienet asiat ovat huomattavasti haastavampia.

\section{LOPUKSI}

Kuten todettu, terminä meänkieli, "meidän pienen vähemmistön oma kieli", heijastaa jo sellaisenaan paikallisella tasolla ilmenevää kiistämisen kulttuuria, jossa käsitys oman identiteetin muodostumisesta yhteiskuntakriittisyyden kautta on tuotu itsetietoisesti käsitteelliselle tasolle. Kaikki paikalliset eivät hyväksy vähemmistökertomusta sellaisenaan, vaan kyseenalaistavat koko termin käyttämisen 
mielekkyyden pitäen terminologisella tasolla meänkieltä paremminkin "keksittynä" kuin luonnollisena osana paikallista identiteettiä. Tärkeä on kuitenkin korostaa sitä, että myös tämä näkökulma, eräänlainen vastakertomuksen vastakertomus, esitetään useimmiten juuri huumorin kautta. Kuten edellä tuotiin esiin, useat meänkieliset pitävät kieltään jo itsessään hauskana, kun taas toisille käsitys meänkielen sisäsyntyisestä koomisuudesta on loukkaus, "heidän" vääristynyt käsitys "meistä". Vaikka mielipiteet kielen ja huumorin suhteesta vaihtelevat eri inmisten ja ryhmien välillä, näitä käsityksiä yhdistää voimakas alueellisen yhteenkuuluvuudentunteen korostaminen.

Tunne yhteisestä, jaetusta identiteetistä muodostuu kertomuksissa, joissa "meidän" ja "heidän" kategorinen ero tehdään selväksi, selkeästi tunnistettavaksi ja luonnolliseksi. Kun paikallisella tasolla vastakertomus mielletään legitiimiksi kertomukseksi, marginaaliaseman haastaminen tapahtuu itsestään. Huumorin yhdistyminen "meidän" ja "heidän" kategoriseen erotteluun on perinteisesti liitetty toiseutta tuottaviin kulttuurisiin käytäntöihin, joissa marginaaliryhmät asetetaan naurun kohteiksi. Kuten tässä artikkelissa on tuotu esiin, huumori voi kuitenkin toimia myös työkaluna, jossa perinteinen tapa ymmärtää vähemmistöryhmien sosiokulttuurista asemaa asettautuu uuteen perspektiiviin.

Huumori pitää siis sisällään emansipatorista potentiaalia, mutta se, kuinka tämä potentiaali tuodaan käytäntöön kulttuurisen toiminnan ja arjen eri tasoilla, on huomattavasti monimutkaisempi kysymys. Kaikki emansipaatioon pyrkivä kulttuurinen toiminta pitää sisällään myös sen riskin, että toteutus jää omien pyrkimystensä vangiksi. Jotta alisteisuutta voidaan kritisoida, on omaa alempiarvoisuutta tuottava valtarakennelma tunnustettava, jolloin kertomus keskuksen ja marginaalin välisestä valtasuhteesta tulee uudelleen kirjoitetuksi. Kysymys on perinteisestä postkoloniaaliseen lähestymistapaan liittyvästä ongelmasta: onko emansipaatioon pyrkivä puhe itse asiassa enemmänkin valtarakenteita vahvistavaa kuin niitä purkavaa toimintaa (vrt. Crush 1994)? Toisaalta, vaikka meänkielisten kanssa käydyissä keskusteluissa korostuukin yhteiskuntakritiikki, alisteisuuden perintö ja sen merkitys osana alueen ihmisten identiteettiä tietyllä tapaa hyväksytään ja sille osataan myös nauraa ilman itsetietoista pyrkimystä kohti vaihtoehtoisten tarinoiden kertomista.

Vaikka vähemmistöidentiteetti syntyy ja muotoutuu "meidät" ja "heidät" erottavissa kertomuksissa, löytyy ryhmien sisältä kuitenkin aina erilaisia näkemyksiä ja kertomuksia siitä, keitä nämä "he" itse asiassa ovat. Meänkielisten tilallisen identiteetin pohjana on samanaikaisesti toiseuden historia osana ruotsalaista yhteiskuntaa ja toisaalta kategorinen erottelu Ruotsin puolisten meänkielisten ja Suomen puolisten Tornionlaakson murretta puhuvien ihmisten välillä. Tässä tutkimuksessa hienoisena yllätyksenä kuitenkin oli, että keskusteluissa meänkielen sosiaalista asemaa alueellisena vähemmistökielenä heijastettiin enemmänkin suomen kieltä ja suomalaista kulttuuria vasten, ei niinkään suhteessa ruotsalaiseen yhteiskuntaan. On toki mahdollista, että tutkijan kansallisuus on ollut tässä keskustelua (alitajuisesti) ohjaavana tekijänä. 
Huumori on kiinteästi yhteydessä yhteenkuuluvuuden tunteeseen, jolla vastaavasti on tämän tutkimuksen tapauksessa selkeä tilallinen ulottuvuus: kyse on raja-alueesta. Raja-alueen arjessa meänkieli ja ruotsin kieli sotkeutuvat synnyttäen tilanteita, joita on hauska muistella jälkeenpäin. Onko meänkieli jo itsessään hauska kieli, on ensisijaisesti kysymys siitä, onko tornionlaaksolainen identiteetti jo lähtökohtaisesti poikkeuksellisen "humoristinen". Kuten keskusteluissa nousi esiin, huumorin tapauksessa kyse on narratiivisesta työkalusta, jonka avulla kertojat ja yleisö voivat puhua vakavistakin asioista, kuten omasta kielellisestä ja alueellisesta marginaalisuudestaan rennolla ja mukavalla tavalla. Huumorin avulla tarinoista tulee herkullisempia ja tunne yhteisestä jaetusta identiteetistä vahvistuu entisestään. Lisäksi paikallinen folklore pysyy yllä huumorin avulla, hauskoissa kertomuksissa, joita on helppo muistella jälkeenpäin ja kuljettaa eteenpäin, sukupolvelta toiselle.

\section{LÄHTEET}

\section{Tutkimusaineistot}

\section{Äänitteet}

Ryhmäkeskustelu 1, kaksi miestä, Haparanda 25.8.2015, haastattelija Juha Ridanpää

Ryhmäkeskustelu 2, neljä naista, Svanstein 14.9.2015, haastattelija Juha Ridanpää Ryhmäkeskustelu 3, kolme miestä, Pajala 22.9.2015, haastattelija Juha Ridanpää

Ryhmäkeskustelu 4, kaksi naista ja yksi mies, Korpilombolo 22.10.2015, haastattelija Juha Ridanpää

Ryhmäkeskustelu 5, kaksi naista, Korpilombolo 12.11.2015, haastattelija Juha Ridanpää

Ryhmäkeskustelu 6, kolme naista ja kaksi miestä, Övertorneå 12.1.2016, haastattelija Juha Ridanpää

Ryhmäkeskustelu 7, kolme naista, Övertorneå 18.1.2016, haastattelija Juha Ridanpää

Ryhmäkeskustelu 8, kolme naista ja seitsemän miestä, Aapua 5.2.2016, haastattelija Juha Ridanpää

Äänitteet ovat tutkimuksen tekijän hallussa.

\section{Kirjallisuus}

Ahola, Laura 2006: Asenteellista menoa - tornionlaaksolaiset nuoret ja vähemmistökieli. -Bamberg, Michael \& Alexandra Georgakopoulou, 2008: Small stories as a new perspective in narrative and identity analysis. - Text \& Talk - An Interdisciplinary Journal of Language, Discourse Communication Studies 28(3): 377-396. 
Billig, Michael 2005: Laughter and Ridicule. Towards a Social Critique of Humour. London: Sage.

Booth, Tim \& Wendy Booth, 1996: Sounds of Silence: Narrative research with inarticulate subjects. - Disability \& Society 11(1): 55-70.

Browne, Alison L. 2016: Can people talk together about their practices? Focus groups, humour and the sensitive dynamics of everyday life. - Area 48(2): 198-205.

Brubaker, Rogers \& Frederick Cooper, 2000: Beyond "identity". - Theory and Society 29(1): 1-47.

Crush, Jonathan. 1994: Post-colonialism, de-colonization, and geography. Godlewska, Anne \& Neil Smith, (eds.), Geography and Empire. USA: Blackwell. 333-350.

Cullblom, Ester 1997: Female Strategies in the Politicians' - Preachers' - Patriarchs' Tornedalen. - Jansson, Robert (eds.), Minorities and Women. Åbo/Turku: Åbo Akademis tryckeri. 73-84.

Cundall, Michael 2012: Towards a better understanding of racist and ethnic humor. - HUMOR: International Journal of Humor Research 25(2): 155-177.

Davies, Christie 1990: Ethnic Humor around the World: A Comparative Analysis. Bloomington: Ind.: Indiana University Press.

Davies, Christie 1998: Jokes and their Relation to Society. Berlin: Druckerei Hildebrand.

Davies, Christie 2002: The Mirth of Nations. New Jersey: Transaction Publishers.

Edwards, John 2010: Minority Languages and Group Identity. Amsterdam: John Benjamins B. V.

Eriksson, Madeleine 2010: (Re)producing a periphery: Popular representations of the Swedish North. Umeå: Department of Social and Economic Geography.

Georgakopoulou, Alexandra 2006: Thinking big with small stories in narrative and identity analysis. - Narrative Inquiry 16(1): 122-130.

Hearn, Mark 2007: Cultivating an Australian Sentiment: John Christian Watson's Narrative of White Nationalism. - National Identities 9(4): 351-368.

Heith, Anne 2012: Ethnicity, Cultural Identity and Bordering: A Tornedalian Negro. - Folklore 52: 85-108.

Hughes, Melissa K. 2003: Through the Looking Glass: Racial Jokes, Social Context, and the Reasonable Person in Hostile Work Environment Analysis. - Southern California Law Review 76(6): 1437-1482.

Hurme, Juha 1996: Hyvä tappaja. - Image 1996(4): 44-47.

Hutcheon, Linda 1994: Irony's edge: the theory and politics of irony. London: Routledge.

Kantokorpi, Mervi 1997: Kymppi juksauksessa. Rosa Liksomia lukiessa. Teoksessa Kantokorpi, Mervi (toim.): Muodotonta menoa: Kirjoituksia nykykirjallisuudesta, 7-29. WSOY, Porvoo.

Knuuttila, Seppo 1992: Kansanhuumorin mieli: Kaskut maailman kuvan aineksena. Helsinki: SKS. 
Knuuttila, Seppo 2015: Huumorin tajunta. - Knuuttila, Seppo \& Hakamies, Pekka \& Lampela, Elina (toim.), Huumorin Skaalat: Esitys, tyyli, tarkoitus. Helsinki: SKS. 7-16.

Kuipers, Giselinde \& Barbara van der Ent, 2016: The seriousness of ethnic jokes: Ethnic humor and social change in the Netherlands, 1995-2012. - HUMOR: International Journal of Humor Research 29(4): 605-633.

Lehtinen, Juuso \& Matti Markkola, 2015: Härski, härskimpi, Suomen kartta - kyllä, nämä yli 1600 roisia paikannimeä löytyvät Suomesta. - I/ta-Sanomat 17.8.2015 [online]. < http://www.iltasanomat.fi/kotimaa/art-2000000977492.html > [22.9.2016.].

Lindgren, Anna-Riitta 2000: Language Emancipation: The Finnish Case. - Phillipson, Robert (toim.), Rights to Language: Equity, Power and Education. Mahwah: Laurence Erlbaum Associates. 40-45.

Luostarinen, Heikki 1997: 'The Quiet Finn': National Stereotypes, Politics and the Media in a Small Country. - Scottish Affairs 20(1): 116-132.

Lynch, Owen 2010: Cooking with humor: In-group humor as social organization. HUMOR: International Journal of Humor Research 23(2): 127-160.

Magnfríður Júlíusdóttir \& Yvonne Gunnarsdotter 2007: Culture, cultural economy and gender in processes of place reinvention. - Nyseth, Torill \& Brynhild Granås, (eds.), Place Reinvention in the North - Dynamics and Governance Perspectives. Stockholm: Nordregio. 39-53.

Mantila, Harri 2000: Meänkieli, yksi Ruotsin vähemmistökielistä. - Kielikello 3/2000 [online]. < http://www.kielikello.fi/index.php?mid=2\&pid=11\&aid=1198 > [7.4.2017.]

Mascha, Efharis 2008: Political satire and hegemony: A case of "passive revolution" during Mussolini's ascendance to power 1919-1925. - HUMOR: International Journal of Humor Research 21(1): 69-98.

Massey, Doreen 2005: For Space. London: Sage.

Niemi, Mikael 2001: Populaarimusiikkia Vittulajänkältä. Jyväskylä: Gummerus.

Palmer, Jerry 1993: Taking Humour Seriously. London: Routledge.

Perks, Lisa Glebatis 2010: Polysemic Scaffolding: Explicating Discursive Clashes in Chapelle's Show. - Communication, Culture and Critique 3(2): 270-289.

Polkinghorne, Donald E. 1995: Narrative configuration in qualitative analysis. International Journal of Qualitative Studies in Education 8(1): 5-23.

Price, Patricia L. 2010: Cultural geography and the stories we tell ourselves. Cultural Geographies 17(2): 203-210.

Prokkola, Eeva-Kaisa \& Juha Ridanpää, 2011: Following the plot of Bengt Pohjanen's Meänmaa: Narrativization as a process of creating regional identity. - Social \& Cultural Geography 12(7): 775-791.

Pöysä, Jyrki 2012: Työelämän alkeismuodot: Narratiivinen etnografia. Joensuu: Suomen Kansantietouden Tutkijain Seura.

Relph, Edward 1976: Place and Placelessness. London: Pion Limited. 
Ridanpää, Juha 2007: Laughing at northernness: postcolonialism and metafictive irony in the imaginative geography. - Social \& Cultural Geography 8(6): 907-928.

Ridanpää, Juha 2010: A Masculinist Northern Wilderness and the Emancipatory Potential of Literary Irony. - Gender, Place \& Culture 17(3): 319-335.

Ridanpää, Juha 2011: Pajala as a literary place: in the readings and footsteps of Mikael Niemi. -Journal of Tourism and Cultural Change 9(2): 104-118.

Ridanpää, Juha 2014a: Politics of literary humour and contested narrative identity (of a region with no identity). - Cultural Geographies 21(4): 711-726.

Ridanpää, Juha 2014b: Seriously Serious Political Spaces of Humor. - ACME: An International E-Journal for Critical Geographies 13(3): 450-456.

Rothwell, Erin ym. 2011: Joking Culture: The Role of Repeated Humorous Interactions on Group Processes During Challenge Course Experiences. Journal of Experimental Education 33(4): 338-353.

Salamon, Hagar 2011: The Floor Falling Away: Dislocated Space and Body in the Humour of Ethiopian Immigrants in Israel. - Folklore 122(1): 16-34.

Shiftman, Limor \& Elihu Katz, 2005: "Just Call Me Adonai": A Case Study of Ethnic Humor and Immigrant Assimilation. - American Sociological Review 70(5): 843-859.

Somers, Margaret R. 1994: The narrative constitution of identity: A relational and network approach. - Theory and Society 23(5): 605-649.

Szerszynski, Bronislaw 2007: The Post-ecologist condition: Irony as symptom and cure. - Environmental Politics 16(2): 337-355.

Terrion, Jenepher Lennox \& Blake E. Ashforth, 2002: From 'I' to 'We': The Role of Putdown Humor and Identity in the Development of a Temporary Group. Human Relations 55(1): 55-88.

Tuan, Yi-Fu 1974: Topophilia: A Study of Environmental Perception, Attitudes and Values. New York: Columbia University Press.

Vaattovaara, Johanna 2009: Meän tapa puhua: Tornionlaakso pellolaisnuorten subjektiivisena paikkana ja murrealueena. Helsinki: SKS.

Weaver, Simon 2011: The Rhetoric of Racist Humour: US, UK and Global Race Joking. Farnham: Ashgate.

Weckström, Lotta 2011: Representations of Finnishness in Sweden. Helsinki: Finnish Literature Society.

Winsa, Birger 2007: Social capital of indigenous and autochthonous ethnicities. - Dana, Léo-Paul \& Robert B. Anderson (eds.), International Handbook of Research of International Entrepreneurship. Chelterham: Edward Elgar Publishing. 257-286.

\section{Filosofian tohtori Juha Ridanpää on kulttuurimaantieteilijä Oulun yliopistosta.}

